\title{
Effect of the levels of calcium and particle size of limestone on laying hens ${ }^{1}$
}

\section{José Anchieta de Araujo², José Humberto Vilar da Silva ${ }^{3}$, Fernando Guilherme Perazzo Costa ${ }^{4}$, Janaína Maria Batista de Sousa ${ }^{5}$, Patrícia Emília Naves Givisiez ${ }^{4}$, Nilva Kazue Sakomura ${ }^{6}$}

\author{
1 Projeto financiado com recursos do CNPq. \\ 2 Programa de Pós-Graduação em Zootecnia - CCA/UFPB. Bolsista CAPES. \\ ${ }^{3}$ DAP/CCHSA/UFPB e PPGZ/CCA/UFPB. Bolsista PQ/CNPq. \\ ${ }^{4}$ Departamento de Zootecnia/CCA/UFPB - Areia, PB. \\ 5 Programa de Pós-Graduação em Tecnologia Agroalimentar-CCHSA/UFPB. \\ ${ }^{6}$ Departamento de Zootecnia/UNESP - Jaboticabal, SP.
}

ABSTRACT - This experiment was conducted to evaluate the effect of levels of calcium (Ca) and particle size of limestone (LS) for laying hens. It was used 216 Dekalb White laying hens at 25 to 49 weeks of age in a completely randomized design in a $3 \times 2$ factorial arrangement, composed of three levels of calcium (3.92, 4.02 and 4.12\%) and two particle sizes of limestone (thin $-0.60 \mathrm{~mm}$; and thick $-1.00 \mathrm{~mm}$ ), resulting in 6 treatments with six replicates of six birds. There was no significant effect of levels of calcium and limestone particle size neither of the interaction calcium $\times$ particle size for feed intake, egg weight, specific gravity, shell thickness, shell percentage, Haugh unit, calcium and phosphorus digestibility and percentage of digestive tract. Production, mass, conversion by mass and conversion by egg dozen had their best results with $4.12 \%$ of calcium in the diet. Percentage of gizzard and feed intake observed at 3:00 p.m. improved as limestone granulometry improved from 0.60 to $1.00 \mathrm{~mm}$. There was an interaction effect among calcium level and limestone granulometry for breaking strength of tibia, bone density, length of the small intestine and feed intake at 6:00 a.m.; 9:00 a.m., 12:00 p.m., 6:00 p.m. and 9:00 p.m., respectively. It is recommended the addition of 4.12\% of calcium and limestone in the thick granulometry $(1.00 \mathrm{~mm})$ for a better performance of commercial laying hens. More studies are needed to elucidate the mechanisms involved in the alteration of nutritional behavior of laying hens in response to changes in the levels of calcium and in the granulometry of limestone in the rations.

Key Words: bone strength, egg quality, performance

\section{Efeito dos níveis de cálcio e da granulometria do calcário para poedeiras comerciais}

RESUMO - O experimento foi realizado para avaliar o efeito dos níveis de cálcio (Ca) e da granulometria do calcário (GC) para poedeiras comerciais. Foram utilizadas 216 poedeiras da linhagem Dekalb White de 25 a 49 semanas de idade em um delineamento inteiramente casualizado, em esquema fatorial $3 \times 2$, composto de três níveis de cálcio (3,92; 4,02 e 4,12\%) e duas granulometrias do calcário (fina - 0,60 mm; e grossa - 1,00 mm), que resultaram em seis tratamentos, com seis repetições de seis aves. Não houve efeito significativo dos níveis de cálcio e da granulometria do calcário nem da interação nível de cálcio $\times$ granulometria do calcário para o consumo de ração, o peso dos ovos, a gravidade específica, a espessura da casca, a porcentagem de casca, a unidade Haugh, a digestibilidade de cálcio e fósforo e a porcentagem do trato digestório. A produção, massa, conversão por massa e conversão por dúzia de ovos tiveram seus melhores resultados com 4,12\% de cálcio na dieta A porcentagem de moela e o consumo de ração observado às $15 \mathrm{~h}$ melhoraram com o aumento na granulometria do calcário de 0,60 para 1,00 mm. Houve efeito da interação entre nível de cálcio e granulometria do calcário para a resistência à quebra da tíbia, a densidade óssea, o comprimento do intestino delgado e o consumo de ração às $6,9,12,18$ e 21 h, respectivamente. Recomenda-se a adição de 4,12\% de cálcio e calcário na granulometria grossa (1,00 mm) para melhor desempenho de poedeiras comerciais. Mais estudos são necessários para elucidar os mecanismos envolvidos na alteração do comportamento alimentar das poedeiras em resposta às mudanças nos níveis de cálcio e na granulometria do calcário das rações.

Palavras-chave: desempenho, qualidade dos ovos, resistência óssea 


\section{Introduction}

The great genetic development of laying hens in recent years has changed important physiological aspects in these birds, requiring further research to equate them (Geraldo, 2006). In this context, the development of body and digestive tract of these birds have been object of concern, with problems related to uniformity of flocks and digestibility of nutrients, affecting their productivity.

Calcium is one of the main elements for maintenance and egg production of laying hens (Narváez et al., 1997) and it has been studied to improve the quality of the eggshell and bone system of modern laying hens, arousing the attention of nutritionists for studies on calcium sources and its physical and chemical characteristics. The calcium requirements by laying hens are considered an ongoing challenge for nutritionists and poultry producers (Roland \& Gordon, 1996). The reasons for this fall on the continuous genetic improvement of commercial strains, in addition to the differences in particle size of limestone, which directly influence the availability of this mineral and poultry ability to adjust feed intake to meet their daily needs. Calcium absorption depends on several factors, including the mineral availability, calcium and phosphorus serum levels, vitamin D3, parathyroid hormone, gastrointestinal $\mathrm{pH}$, fiber and fat contents and mineral granulomety in the diet (Stringhini, 2004).

The reason for the larger grain size of the calcium source for laying hens is related to improved availability of dietary calcium in the evening period, concomitantly with the eggshell formation in the shell gland. According to Leeson \& Summers (1997), limestone with large particles are longer retained in the gizzard, and by being dissolved more slowly, the chicken has a strategic reserve of calcium to be used at the time the egg is being formed in the shell gland.

This study was conducted to evaluate the effects of calcium levels and particle size of limestone on the growth performance and feeding behavior of light laying hens in the stage of egg production.

\section{Material and Methods}

Experiment 1 was conducted at the Laboratório de Pesquisa em Nutrição de Aves of the Centro de Ciências Humanas, Sociais e Agrárias (CCHSA), campus III of the Universidade Federal da Paraíba, located in the city of Bananeiras - PB, micro-region of the Paraiba marsh. The experiment was constituted of six periods of 28 days. It was used 216 Dekalb White hens at 25 weeks of age. Poultry were selected by weight and, after two weeks of feeding on a single diet they were again selected based on the eggs production, so that poultry with extreme means of production were discarded whereas the others were weighed in a group of six and distributed in cages. Each cage had nipple drinker for every four hens housed and a trough-type feeder at the front of the cage.

In parallel with the first experiment, it was performed a digestibility trial (experiment 2) by using the method of total excreta collection. A group of 72 poultry were weighed and housed in a battery of cages equipped with trays to allow the collection of total excreta. The birds were fed on the 12 experimental diets for 10 days (five days for adaptation and five of excreta collection).

Experiments 1 and 2 were conducted in a randomized design, in a $3 \times 2$ factorial arrangement, with three levels of calcium (3.92, 4.02 and 4.12\%) and two limestone particle sizes (thin $=0.60 \mathrm{~mm}$ and thick $=1.00 \mathrm{~mm}$ ), which resulted in six combinations, evaluated with six repetitions of six birds. It was offered $120 \mathrm{~g}$ of feed/bird/day with water ad libitum throughout the experimental period. The experimental diets were formulated based on corn and soybean meal, according to the dietary recommendations of Rostagno et al. (2005) for light commercial layers, except calcium, which was supplemented by the addition of limestone to replace the inert (washed sand).

A diet with adequate calcium level (Rostagno et al., 2005), 4.02\%, was included as positive control and two diets (isoproteic and isocaloric) containing low (3.92\%) and high (4.12\%) calcium content, were formulated to meet or to exceed the nutritional requirements of calcium for poultry (Table 1). The particle size of limestone was obtained by analysis in sieves shaker, according to the standards of the supplier, considering as fine granulometry 30 to $50 \%$ of limestone retained on the $0.60 \mathrm{~mm}$ sieve and coarse 50 to $80 \%$ of limestone retained on the $1.00 \mathrm{~mm}$ sieve. Regardless of particle size (fine or coarse), the limestone was used to guarantee a minimum level of $38 \%$ calcium.

Dead poultry and food scraps were considered to adjust the consumption, egg production and food conventions per mass and per dozen eggs.

The average temperatures registered in the experiment were $21.6^{\circ} \mathrm{C}$ (minimal temperature) and $32.0^{\circ} \mathrm{C}$ (maximal termperature). Minimal and maximal relative humidity were 39 and 85\% respectively, and they were recorded by using a digital thermo-hygrometer at 9:00 a.m. and 5:00 p.m. The lowest temperatures were recorded at night and the highest in the day when feed intake is increased.

The food scraps removed from the trough feeder and buckets were weighed at the end of each period. Egg production was daily recorded; the average egg weight and 
Table 1 - Composition of experimental diets

\begin{tabular}{|c|c|c|c|}
\hline \multirow[t]{2}{*}{ Food } & \multicolumn{3}{|c|}{ Calcium level (\%) } \\
\hline & 3.920 & $4.020 *$ & 4.120 \\
\hline Corn & 61.790 & 61.790 & 61.790 \\
\hline Soybean meal $45 \%$ & 23.556 & 23.556 & 23.556 \\
\hline Limestone & 9.023 & 9.283 & 9.543 \\
\hline Soybean oil & 1.645 & 1.645 & 1.645 \\
\hline Dicalcium phosphate & 1.549 & 1.549 & 1.549 \\
\hline Corn gluten $60 \%$ & 1.024 & 1.024 & 1.024 \\
\hline Inert (washed sand) & 0.522 & 0.262 & 0.002 \\
\hline Salt & 0.497 & 0.497 & 0.497 \\
\hline DL-methionine & 0.183 & 0.183 & 0.183 \\
\hline Vitamin premix $^{1}$ & 0.100 & 0.100 & 0.100 \\
\hline Mineral Premix ${ }^{2}$ & 0.050 & 0.050 & 0.050 \\
\hline Choline chloride $70 \%$ & 0.050 & 0.050 & 0.050 \\
\hline Butylated hydroxy toluene & 0.010 & 0.010 & 0.010 \\
\hline \multicolumn{4}{|l|}{ Calculated composition } \\
\hline Metabolizable energy (kcal/kg) & 2.800 & 2.800 & 2.800 \\
\hline Crude protein (\%) & 16.500 & 16.500 & 16.500 \\
\hline Calcium (\%) & 3.920 & 4.020 & 4.120 \\
\hline Available phosphorus (\%) & 0.380 & 0.380 & 0.380 \\
\hline Digestible methionine (\%) & 0.431 & 0.431 & 0.431 \\
\hline Digest. methionine+cystine (\%) & 0.668 & 0.668 & 0.668 \\
\hline Digestible lysine (\%) & 0.731 & 0.731 & 0.731 \\
\hline Digestible threonine (\%) & 0.559 & 0.559 & 0.559 \\
\hline Digestible tryptophan (\%) & 0.174 & 0.174 & 0.174 \\
\hline Digestible arginine (\%) & 0.984 & 0.984 & 0.984 \\
\hline Digestible valine (\%) & 0.690 & 0.690 & 0.690 \\
\hline Sodium (\%) & 0.220 & 0.220 & 0.220 \\
\hline Chlorine (\%) & 0.339 & 0.339 & 0.339 \\
\hline Potassium (\%) & 0.621 & 0.621 & 0.621 \\
\hline
\end{tabular}

*Recommended by Rostagno et al. (2005).

${ }^{1}$ Composition per kg of product: A vit. - 10,000,000 IU; D3 vit. - 2,500,000 IU; E vit. - 6,000 IU; K vit. - 1,600 mg; B12 vit. - 11,000 mg; Niacin - 25,000 mg; folic acid - $400 \mathrm{mg}$; pantothenic acid - 10,000 mg; Se - $300 \mathrm{mg}$.

${ }^{2}$ Composition per kg of product: MN - 150,000 mg; zinc - 100,000 mg; iron 100,000 mg; copper - 16,000 mg; iodine - 1,500 mg.

specific gravity of eggshells were obtained in the last five days of each experimental period.

The variables studied in experiment 1 were feed intake, egg production, egg weight, egg mass, conversion per mass and per dozen eggs, specific gravity, eggshell, eggshell percentage, eggshell thickness and Haugh unit.

The specific gravity of eggshell was determined by floating eggs method in 17 salt solutions, ranging in density from 0.0025 unit, starting from 1.060 to 1.100 (Butcher \& Miles, 2003).

To determine shell thickness, measurements were taken at three points in the equatorial region of the egg, with a Mitutoyo micrometer. At the end of each period, three eggs per plot were analyzed, weighed on a $0.01 \mathrm{~g}$ precision digital scale and broken on a glass flat surface to obtain the height of the albumen, by using an altimeter (Ames). Haugh unit values were calculated according to the formula presented by Card \& Nesheim (1966). At the end of experiment 1, two poultry per plot were sacrificed after fasting for two hours to assess the gizzard weight. It was taken the digestive tract weight from the proventriculus to the rectum, including the cecum and pancreas, and liver was removed. Results were expressed as body weight percentage (Choi et al., 1986).

The small intestine length (duodenum to ileum) was measured by using a tape measure, and intestine extended on a flat surface for measurement. The relative length of the small intestine was expressed in $\mathrm{cm} / \mathrm{kg}$ body weight (Choi et al., 1986).

The left tibia of each poultry was removed and used in the analysis of shear strength with three point bending. The analysis was performed on an Instron (kgf) press of the Departamento de Engenharia Civil of the Universidade Federal de Campina Grande, Paraíba.

For bone densitometry, radiograph images of the right tibia were obtained. After extraction of soft tissues and ligaments, bones were radiographed together with the density reference in an X-ray Siemens Tridoros 812E machine with a capacity of 38 kilovolt (KV), four milliamps and 10 seconds. As a densitometric reference in radiographs, it was used an aluminum ladder (6063, ABNT) of 12 steps ( $0.5 \mathrm{~mm}$ thick for the first step) ranging from 0.5 to $0.5 \mathrm{~mm}$ until the $10^{\text {th }}$ step, the $11^{\text {th }}$ with $6.0 \mathrm{~mm}$ thick and the $12^{\text {th }}$ with $8.0 \mathrm{~mm}$ thick, each step with $5 \times 25 \mathrm{~mm}^{2}$ area.

After being $\mathrm{X}$-rayed, the images were scanned in an HP scanner (Scanjet 4C - Brazil), with transparency adapter for HP Scanjet 4C, and stored in a microcomputer. In densitometric analysis, it was used the Image-Pro Plus (Media Cybernetics - USA) software, which recaptured the radiographed images, being made initially the density calibration and bone density measurement in millimeters of equivalent aluminum (mmAl).

The program calibration was carried out by selecting specific density regions in the aluminum ladder. The values obtained led to a standard curve which was correlated to the values found on bone scans of interest. The reading of bone density was performed at three points (proximal epiphysis, diaphysis and distal epiphysis) of the right tibia of light laying hens at 49 weeks of age.

During the experiment 1 , it was conducted an evaluation of the feeding behavior at the end of the second, fourth and sixth periods, respectively. In this evaluation, feed intake was controlled, being provided $150 \mathrm{~g}$ feed/poultry. The feed offers occurred at 5:00 a.m. and weights for measuring consumption at 6:00 a.m.; 9:00 a.m.; 12 p.m.; 3:00 p.m., 6:00 p.m. and 9:00 p.m., respectively.

In experiment 2, excreta samples were taken twice daily, in the morning and in the afternoon, weighed and a $10 \%$ aliquot was stored in a freezer at $-10^{\circ} \mathrm{C}$ until laboratory analysis. The contents of total calcium in the diets and excreta were analyzed by spectrophotometer. Subsequently, 
mineral digestibility was calculated (calcium and phosphorus). The test was conducted in a completely randomized design with 12 combinations, each one with three replicates of two birds.

Statistical analysis was performed by using the program SAEG 5.0, developed by the Universidade Federal de Viçosa - UFV (1983). After the analysis of variance, when interactions were significant, the effects of each level of a major factor were studied within the other. In the absence of significant interaction, main effects were assessed by SNK test $(\mathrm{P}<0.05)$.

\section{Results and Discussion}

There was no significant effect $(\mathrm{P}>0.05)$ in calcium levels and particle size of limestone, or the interaction between these two factors on feed intake (Table 2). This result corroborates studies in literature which point out that there was no influence of particle size of limestone in feed consumption (Oliveira et al., 2002, Geraldo et al., 2004, Couto et al., 2008).
Egg production has improved $(\mathrm{P}<0.01)$ with $4.12 \%$ calcium in the diet. However, there was no significant effect ( $\mathrm{P}>0.05)$ of limestone particle size, which contradicts, in part, the results described by Geraldo et al. (2006), who found a positive residual effect of fine granulometry in phases of rearing and re-rearing of hens on the average egg production at the production stage. There was no effect $(\mathrm{P}>0.05)$ of calcium levels and particle size of limestone on the egg weight. Geraldo et al. (2006), studying calcium levels and particle sizes of limestone for hens and their effects on yield and quality of eggs, also found no difference in egg weight among groups, then the calcium level and particle size of limestone used did not affect the egg weight.

Regardless of limestone granulometry, the best results for egg mass were observed with $4.12 \%$ calcium provided all day. This result exceeds the level of $4.02 \%$ calcium recommended by Rostagno et al. (2005) for light laying hens. The best conversions per mass and per dozen eggs $(\mathrm{P}<0.01)$ were observed with $4.12 \%$ calcium in the diet (Table 3). There was no effect of limestone particle size on these variables. Ito et al. (2006) studied the fractionation of

Table 2 - Feed intake, egg production, egg weight and egg mass in laying hens fed diets with three levels of calcium

\begin{tabular}{|c|c|c|c|c|}
\hline Calcium level (\%) & Feed intake (g/bird/day) & Production (\%/hen/day) & Egg weight (g) & Egg mass $(\mathrm{g} / \mathrm{g})$ \\
\hline 3.92 & 102.166 & $80.677 \mathrm{~b}$ & 62.468 & $50.465 b$ \\
\hline 4.02 & 102.433 & $77.640 \mathrm{c}$ & 62.794 & $48.800 \mathrm{~b}$ \\
\hline 4.12 & 103.051 & $84.184 \mathrm{a}$ & 62.669 & $52.871 \mathrm{a}$ \\
\hline \multicolumn{5}{|l|}{ Particle size } \\
\hline Thin $(0.6 \mathrm{~mm})$ & 102.215 & 80.615 & 62.502 & 50.478 \\
\hline Thick $(1.0 \mathrm{~mm})$ & 102.885 & 81.052 & 62.785 & 50.946 \\
\hline Particle size of limestone & ns & ns & ns & ns \\
\hline Level of calcium $\times$ particle size of limestone & ns & ns & ns & ns \\
\hline Coefficient of variation (\%) & 1.127 & 2.185 & 2.507 & 3.327 \\
\hline
\end{tabular}

Means in columns followed by different letters are different $(\mathrm{P}<0.01)$ by SNK test.

Table 3 - Feed conversion by egg mass, feed conversion per dozen eggs and egg specific gravity of hens fed diets containing three levels of calcium

\begin{tabular}{lccc}
\hline Calcium level (\%) & Egg mass conversion $(\mathrm{kg} / \mathrm{kg})$ & Egg dozen conversion $(\mathrm{kg} / \mathrm{dz})$ & Specific gravity $\left(\mathrm{g} / \mathrm{cm}^{3}\right)$ \\
\hline 3.92 & $2.072 \mathrm{~b}$ & $2.456 \mathrm{a}$ & 1.0896 \\
4.02 & $2.147 \mathrm{a}$ & $2.513 \mathrm{a}$ & 1.0887 \\
4.12 & $1.989 \mathrm{c}$ & $2.180 \mathrm{~b}$ & 1.0886 \\
Particle size & & & \\
Thin $(0.6 \mathrm{~mm})$ & 2.077 & 2.401 & 1.0886 \\
Thick $(1.0 \mathrm{~mm})$ & 2.062 & 2.365 & 1.0893 \\
Analysis of variance & & & $\mathrm{ns}$ \\
Calcium level & $* *$ & $* *$ & $\mathrm{~ns}$ \\
Particle size of limestone & $\mathrm{ns}$ & $\mathrm{ns}$ & $\mathrm{ns}$ \\
Level of calcium $\times$ particle size of limestone & $\mathrm{ns}$ & 10.265 & 0.184 \\
Coefficient of variation $(\%)$ & 3.174 & & \\
\hline
\end{tabular}

Means in columns followed by different letters are different $(\mathrm{P}<0.01)$ by SNK test. 
dietary calcium and limestone particle size on laying hens performance and noticed no significant effect $(\mathrm{P}>0.05)$ of limestone particle size on the feed conversion per mass and per dozen eggs.

The specific gravity was not affected $(\mathrm{P}>0.05)$ by the main factors (calcium level and limestone particle size) or by their interaction. This result contradicts that obtained by Ito et al. (2006), who observed eggshell specific gravity reduction obtained by providing diets containing fine granulometry compared to the diets with limestone of coarse and mixed granulometry.

There was no significant effect ( $\mathrm{P}>0.05$ ) of calcium levels and particle size of limestone, or their interaction on the shell thickness, shell percentage and Haugh unit (Table 4).

A result opposite to that observed in this study was described by Pavloviski et al. (2003), who evaluated the replacement of powdered limestone (fine granulometry) for 60 or $80 \%$ granular limestone (coarse granulometery) and noted improvement in the eggshell quality (greater thickness and shell weight, higher breaking strength and lower shell deformation); however, there is evidence in the literature that there is no influence of limestone particle size in the eggshell percentage (Jardim Filho et al., 2005, Gerard et al., 2006, Ito et al., 2006), indicating that the hens were able to assimilate well the limestone offered, preserving the shell quality. For Haugh unit, Ito et al. (2006) found no significant effect $(\mathrm{P}>0.05)$ of the calcium fractionation or limestone particle size, as observed in this result. There was no significant effect $(\mathrm{P}>0.05)$ of calcium levels and granulometry or their interaction, on the digestibility of calcium and phosphorus (Table 5).

This was probably caused by the small spacing among the levels of calcium studied. Pelica et al. (2009) commented that animals fed diets deficient in this mineral had increased their absorption rates whereas high dietary levels caused reduction. These same authors noted that the increased level of dietary calcium from 3 to $4.5 \%$ increases the calcium losses in the feces of laying hens.

According to Roland (1986), larger particles from the source, inadequate levels and exposure to factors that reduce the use of calcium improves the availability of this mineral in chickens and help to explain the lack of effect of

Table 4 - Thickness, eggshell percentage and egg Haugh unit of laying hens fed diets with three levels of calcium

\begin{tabular}{|c|c|c|c|}
\hline Calcium level (\%) & Thickness (mm) & Eggshell (\%) & Unit Haugh \\
\hline 3.92 & 0.426 & 9.777 & 93.886 \\
\hline 4.02 & 0.444 & 9.916 & 89.111 \\
\hline 4.12 & 0.454 & 9.386 & 88.843 \\
\hline \multicolumn{4}{|l|}{ Particle size } \\
\hline Thin $(0.6 \mathrm{~mm})$ & 0.433 & 9.613 & 91.612 \\
\hline Thick $(1.0 \mathrm{~mm})$ & 0.449 & 9.773 & 89.614 \\
\hline \multicolumn{4}{|l|}{ Analysis of variance } \\
\hline Calcium level & ns & ns & ns \\
\hline Particle size of limestone & ns & ns & ns \\
\hline Level of calcium $\times$ particle size of limestone & ns & ns & ns \\
\hline Coefficient of variation (\%) & 4.960 & 3.837 & 3.694 \\
\hline
\end{tabular}

Table 5 - Mineral digestibility of experimental diets, breaking strength and bone density of tibia in laying hens fed diets with three levels of calcium

\begin{tabular}{|c|c|c|c|c|}
\hline \multirow[t]{2}{*}{ Calcium level (\%) } & \multicolumn{2}{|c|}{ Mineral digestibility } & \multirow{2}{*}{$\begin{array}{l}\text { Strength } \\
(\mathrm{kgf} / \mathrm{mm})\end{array}$} & \multirow{2}{*}{$\begin{array}{l}\text { Density } \\
(\mathrm{mmAl})\end{array}$} \\
\hline & Calcium (\%) & Phosphorus (\%) & & \\
\hline 3.92 & 85.886 & 79.447 & 12.749 & 2.542 \\
\hline 4.02 & 84.919 & 82.901 & 15.299 & 2.730 \\
\hline 4.12 & 82.562 & 79.300 & 13.113 & 2.474 \\
\hline \multicolumn{5}{|l|}{ Particle size } \\
\hline Thin (0.6 mm) & 84.383 & 78.338 & $12.628 b$ & 2.581 \\
\hline Thick (1.0 mm) & 84.528 & 82.760 & $14.813 \mathrm{a}$ & 2.583 \\
\hline \multicolumn{5}{|l|}{ Analysis of variance } \\
\hline Calcium level & ns & ns & ns & ns \\
\hline Particle size of limestone & ns & ns & $*$ & ns \\
\hline Level of calcium $\times$ particle size of limestone & ns & ns & $*$ & $* *$ \\
\hline Coefficient of variation (\%) & 6.513 & 6.273 & 19.867 & 11.934 \\
\hline
\end{tabular}

Means in columns followed by different letters are different $(\mathrm{P}<0.01)$ by SNK test.

*Significant effect by SNK test $(\mathrm{P}<0.05)$. **Significant effect $(\mathrm{P}<0.01)$ by SNK test. 
experimental diets on the calcium digestibility. Furthermore, the use of levels very close to calcium requirements for poultry did not come to induce calcium deficiency and excess. There was no significant effect $(\mathrm{P}>0.05)$ of calcium levels on the tibia bone resistance to fracture. However, the coarse texture of the limestone improved $(\mathrm{P}<0.05)$ resistance. The interaction calcium $\times$ granulometry improved $(\mathrm{P}<0.05)$ the tibia bone resistance to breakage when using $4.12 \%$ calcium associated with coarse limestone (Table 6).

Results of Fleming et al. (1998) found better bone resistance when added in the form of limestone gravel to feed. However, Jardim Filho (2005), working on different sources and textures of limestone in the diet of laying hens, observed no effect on bone resistance in hens until 49 weeks of age. For Saunders-Blades et al. (2009), diets containing coarse particles of limestone can improve the welfare of laying hens by reducing cases of osteoporosis and preventing the suffering of poultry with bones breaking at the end of the production cycle.

Bone density was not affected $(\mathrm{P}>0.05)$ by calcium levels or limestone granulometry, which did not occur $(\mathrm{P}<0.01)$ when $4.12 \%$ calcium and coarse limestone were combined (Table 6). Paz et al. (2008), evaluating bone density in laying hens, found differences among levels tested for the tibia density and stated that bones of poultry fed 3.8\% calcium had higher densities than those fed on $1.8 \%$ calcium. This proves that the elevated levels of calcium in the diet increases bone density. The best result of the interaction (calcium level and limestone particle size) on bone density coincided with the best result of bone resistance to breakage, which occurred at $4.12 \%$ calcium associated with coarse limestone indicating a positive and narrow correlation between results of these two variables. No significant effects $(\mathrm{P}>0.05)$ of calcium levels and limestone particle size or their interaction (calcium $\times$ size) were observed on the digestive tract proportion to the body weight of laying hens during production stage (Table 7). The result is consistent with the findings of Geraldo et al. (2006), who noted no significant effect of calcium and limestone texture on the digestive tract percentage of laying hens.

There was no significant effect $(\mathrm{P}>0.05)$ of the interaction between calcium levels and limestone particle size on the gizzards percentage. The low (3.92\%) and high $(4.12 \%)$ calcium levels promoted the best results $(\mathrm{P}<0.01)$ for gizzards percentage than the control (4.02\%).

The use of coarse limestone in the $\operatorname{diet}(\mathrm{P}<0.01)$ caused a higher percentage of gizzards than the fine limestone granulometry. This result may be related to the greater

Table 6 - Effect of interaction between calcium levels and particle size of lime on the breaking strength, bone density of the tibia and the length of the small intestine of laying hens

\begin{tabular}{|c|c|c|c|c|c|c|}
\hline \multirow[t]{3}{*}{ Calcium level (\%) } & \multicolumn{2}{|c|}{ Strength $(\mathrm{kgf} / \mathrm{mm})$} & \multicolumn{2}{|c|}{ Density (mmAl) } & \multicolumn{2}{|c|}{ Small intestine $(\mathrm{cm} / \mathrm{kg})$} \\
\hline & \multicolumn{2}{|c|}{ Granulometry } & \multicolumn{2}{|c|}{ Granulometry } & \multicolumn{2}{|c|}{ Granulometry } \\
\hline & Thin & Thick & Thin & Thick & Thin & Thick \\
\hline 3.92 & $13.11 \mathrm{Aa}$ & $12.39 \mathrm{Aa}$ & $2.71 \mathrm{Aa}$ & $2.37 \mathrm{Ba}$ & $100.25 \mathrm{Aa}$ & $103.07 \mathrm{ABa}$ \\
\hline 4.02 & $14.57 \mathrm{Aa}$ & $16.03 \mathrm{Aa}$ & $2.48 \mathrm{Aa}$ & $2.98 \mathrm{Aa}$ & $100.97 \mathrm{Aa}$ & $96.73 \mathrm{Ba}$ \\
\hline 4.12 & $10.20 \mathrm{Ab}$ & $16.03 \mathrm{Aa}$ & $2.55 \mathrm{Aa}$ & $2.39 \mathrm{Ba}$ & $96.37 \mathrm{Ab}$ & 106.14Aаa \\
\hline CV (\%) & \multicolumn{2}{|c|}{19.867} & \multicolumn{2}{|c|}{11.934} & \multicolumn{2}{|c|}{4.826} \\
\hline
\end{tabular}

Means followed by at least one capital letter in the same column and tiny line do not differ at 5\% probability by SNK test. $\mathrm{CV}=$ Coefficient of variation.

Table 7 - Morphometric measurements of the digestive tract, gizzard and small intestine length in hens fed diets with three levels of calcium

\begin{tabular}{|c|c|c|c|}
\hline Calcium level (\%) & Digestive tract $(\% / \mathrm{kg}$ of $\mathrm{PV})$ & Gizzard $(\% / \mathrm{kg}$ of $\mathrm{PV})$ & Small intestine $(\mathrm{cm} / \mathrm{kg}$ of $\mathrm{PV})$ \\
\hline 3.92 & 8.966 & $1.764 \mathrm{a}$ & 101.658 \\
\hline 4.02 & 9.560 & $1.456 b$ & 98.849 \\
\hline 4.12 & 9.474 & $1.713 \mathrm{a}$ & 101.253 \\
\hline \multicolumn{4}{|l|}{ Particle size } \\
\hline Thin $(0.6 \mathrm{~mm})$ & 9.190 & $1.302 b$ & 99.193 \\
\hline Thick $(1.0 \mathrm{~mm})$ & 9.476 & $1.987 \mathrm{a}$ & 101.980 \\
\hline \multicolumn{4}{|l|}{ Analysis of variance } \\
\hline Calcium level & ns & $* *$ & ns \\
\hline Particle size of limestone & ns & $* *$ & ns \\
\hline Level of calcium $\times$ particle size of limestone & ns & ns & $* *$ \\
\hline Coefficient of variation (\%) & 15.735 & 12.779 & 4.826 \\
\hline
\end{tabular}

Means in columns followed by different letters are different $(\mathrm{P}<0.01)$ by SNK test.

$\mathrm{PV}=$ Weight. 
retention of limestone gravels in the gizzard. A similar effect of coarse ground limestone on the increase of gizzard proportion was noted by several authors, who attributed these results to larger amounts of this mineral source retained in the gizzard of poultry (Rao \& Roland, 1992, Zhang \& Coon, 1997), improving calcium intake. There was no significant effect $(\mathrm{P}>0.05)$ of calcium levels or limestone particle size on the small intestine length. The interaction calcium levels $\times$ limestone particle size had no effect $(\mathrm{P}<0.01)$ on this variable when it was used $4.12 \%$ calcium associated with coarse limestone ( $1.00 \mathrm{~mm}$; Table 6$)$, and this indicates that the limestone fine texture affects the intestinal length.

Geraldo et al. (2006) found no significant effect of calcium levels or limestone particle size on the small intestine length. However, the use of limestone with coarse texture result in a larger quantity of this ingredient retained in the gut of birds (Bertechini, 2006), which explains the longer length of this part of the intestine of birds.

The assessment of feeding behavior showed some intriguing results, starting with the significant effect on poultry consumption from 5 to 6 a.m. $(\mathrm{P}<0.01)$, when birds fed diets containing 3.92\% calcium had peak of feed intake at this time, much higher than that of birds fed other calcium levels (4.02 and 4.12\%). The limestone particle size affected $(\mathrm{P}<0.01)$ feed intake until 6:a.m. in the morning (Table 8). The combination of calcium levels and limestone particle size also influenced $(\mathrm{P}<0.01)$ until 6 a.m., when $3.92 \%$ calcium associated with limestone fine particle size resulted in higher consumption (Table 9).

From 6:00 a.m. to 9:00 a.m. (Table 8), feed intake began to stabilize among calcium levels and it was significantly higher $(\mathrm{P}<0.01)$ at $4.12 \%$. The limestone particle size did not affect $(\mathrm{P}>0.05)$ consumption from 6:00 a.m. to 9:00 a.m., however, the interaction calcium levels $\times$ limestone particle size had effect $(\mathrm{P}<0.05)$ at this period of day inasmuch as $4.12 \%$ calcium regardless of limestone particle size, resulted in higher feed intake (Table 9).

Feed intake from 9:00 a.m. to 12:00 p.m. was higher $(\mathrm{P}<0.05)$ in birds fed the diet with $3.92 \%$ calcium, but this result did not differ from that obtained with $4.12 \%$ calcium in the diet. Feeding behavior at this time of day was inversely proportional to that at 9:00 a.m., when the lowest intakes

Table 8 - Feed intake as a function of calcium level and limestone particle size for laying hens

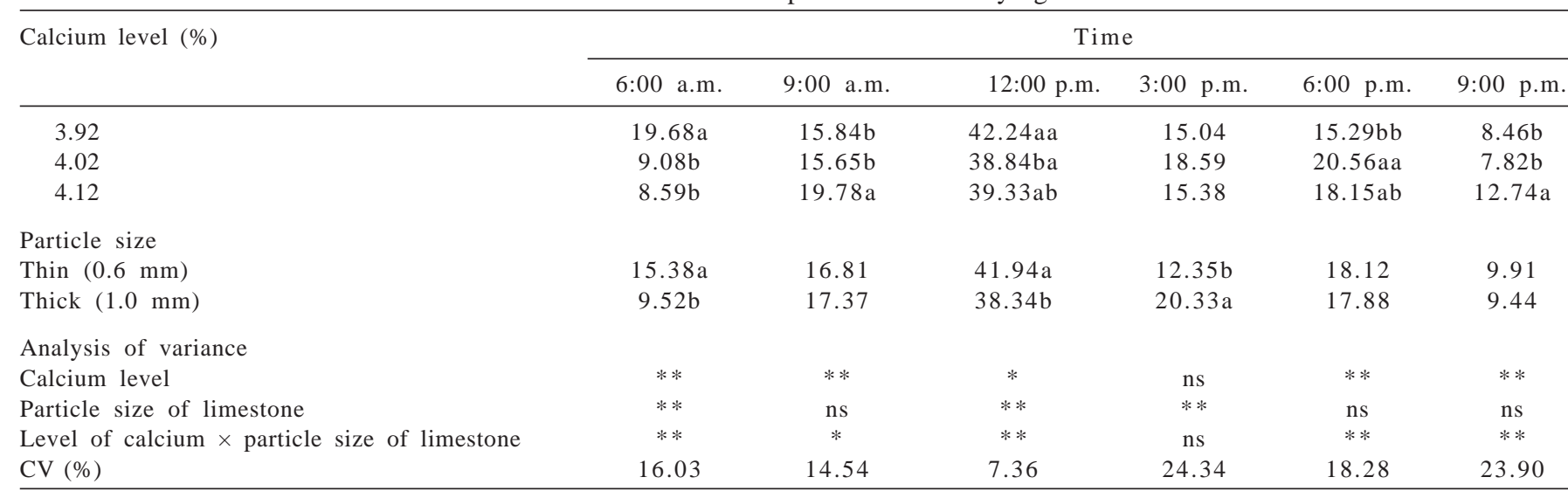

Means in columns followed by different letters are different $(\mathrm{P}<0.01)$ by SNK test.

* Significant effect by SNK test $(\mathrm{P}<0.05)$.

** Significant effect by SNK test $(\mathrm{P}<0.01)$.

$\mathrm{CV}=$ Coefficient of variation.

Table 9 - Effect of the interaction levels of calcium $\times$ particle size of limestone in the feed intake of laying hens measured at 6:00 a.m., 9:00 a.m., 12:00 p.m., 3:00 p.m., 6:00 p.m. and 9:00 p.m.

\begin{tabular}{|c|c|c|c|c|c|c|c|c|c|c|}
\hline \multirow{4}{*}{$\begin{array}{l}\text { Calcium } \\
\text { level (\%) }\end{array}$} & \multicolumn{10}{|c|}{ Time } \\
\hline & \multicolumn{2}{|c|}{ 6:00 a.m. } & \multicolumn{2}{|c|}{ 9:00 a.m. } & \multicolumn{2}{|c|}{ 12:00 p.m. } & \multicolumn{2}{|c|}{ 6:00 p.m. } & \multicolumn{2}{|c|}{ 9:00 p.m. } \\
\hline & \multicolumn{2}{|c|}{ Granulometry } & \multicolumn{2}{|c|}{ Granulometry } & \multicolumn{2}{|c|}{ Granulometry } & \multicolumn{2}{|c|}{ Granulometry } & \multicolumn{2}{|c|}{ Granulometry } \\
\hline & Thin & Thick & Thin & Thick & Thin & Thick & Thin & Thick & Thin & Thick \\
\hline 3.92 & $24.680 \mathrm{Aa}$ & $14.683 \mathrm{Ab}$ & $14.315 \mathrm{BaA}$ & $17.369 \mathrm{ABa}$ & $38.942 \mathrm{Bb}$ & $45.540 \mathrm{Aa}$ & $17.868 \mathrm{Aa}$ & 12.706BaB & $9.592 \mathrm{Aa}$ & 7.320Ba \\
\hline 4.02 & $12.512 \mathrm{Ba}$ & $5.647 \mathrm{Ba}$ & $17.048 \mathrm{ABa}$ & 14.247BaB & $40.031 \mathrm{Ba}$ & $37.642 \mathrm{Ba}$ & $17.884 \mathrm{Aa}$ & 23.229AаA & 8.962Aa & $6.686 \mathrm{Ba}$ \\
\hline 4.12 & 8.941Ca & $8.234 \mathrm{Ba}$ & $19.073 \mathrm{AaB}$ & $20.484 \mathrm{AaA}$ & 46.833Аа & $31.824 \mathrm{Cb}$ & $18.597 \mathrm{Aa}$ & $17.712 \mathrm{ABa}$ & $11.180 \mathrm{Aa}$ & $14.301 \mathrm{Aa}$ \\
\hline CV (\%) & \multicolumn{2}{|c|}{16.033} & \multicolumn{2}{|c|}{14.536} & \multicolumn{2}{|c|}{7.362} & \multicolumn{2}{|c|}{18.281} & \multicolumn{2}{|c|}{23.897} \\
\hline
\end{tabular}

Means followed by at least one capital letter in the column and small letter in line do not differ at 5\% probability by SNK test.

$\mathrm{CV}=$ Coefficient of variation 
were observed for poultry fed on the diet with 3.92 and $4.02 \%$ calcium.

At 12:00 p.m., there was no significant effect $(\mathrm{P}<0.05)$ of limestone of particle size on feed intake, whose highest $(\mathrm{P}<0.01)$ value was obtained with the fine grains. The combination of calcium levels and limestone particle size also affected $(\mathrm{P}<0.01)$ feed intake from 9:00 a.m. to 12:00 p.m.; the highest values were obtained with 4.12\% calcium associated with fine particle size (Table 9).

From 12:00 p.m. to 3:00 p.m., feed intake was not affected $(\mathrm{P}>0.05)$ by calcium or by the interaction calcium levels $\times$ limestone particle size, indicating balance among calcium levels. The coarse limestone influenced $(\mathrm{P}<0.01)$ feed intake more than fine granulometry. This increased consumption of diets with limestone with a $1 \mathrm{~mm}$ limestone at the hottest time of a day (from 12:00 p.m. to 3:00 p.m.) was very important because it certainly led to greater retention of limestone gravels in the gizzard, increasing the input of calcium in the afternoon and in the evening (Rao \& Roland, 1992; Zhang \& Coon, 1997), when the formation of the eggshell is initiated and completed, respectively.

The consumption of diet with $4.02 \%$ calcium was the highest in the period from 3:00 p.m. to 6:00 p.m. $(\mathrm{P}<0.01)$, but it did not differ $(\mathrm{P}>0.05)$ statistically from that obtained at $4.12 \%$ calcium. At this time, limestone particle size as an isolate factor did not affect feed intake; however, the interaction calcium levels $\times$ limestone particle size improved $(\mathrm{P}<0.01)$ feed intake in poultry fed the diet with $4.02 \%$ calcium and coarse limestone.

From 6:00 p.m. to 9:00 p.m., there was a reduction in feed intake for the day: the highest consumption $(\mathrm{P}<0.01)$ at this time was recorded in birds fed the diet with $4.12 \%$ calcium. The limestone particle size as an isolate factor did not affect feed intake, but the interaction calcium levels $\times$ limestone particle size improved $(\mathrm{P}<0.01)$ consumption when birds were fed diet with $4.12 \%$ calcium and coarse limestone.

The highest feed consumption measured throughout the day via feeding behavior of laying hens occurred between 9:00 a.m. and 12:00 p.m., a result which contradicts those obtained by Xin et al. (2002) that indicate the increase in food consumption at around 3:00 p.m.

\section{Conclusions}

The addition of $4.12 \%$ calcium together with the supply of coarse limestone $(1.00 \mathrm{~mm})$ improves the performance of laying hens without affecting the quality of bones and eggs. More studies are needed to elucidate the mechanisms involved in changing the eating behavior of hens in response to changes in calcium levels and limestone particle size in the diet.

\section{References}

BERTECHINI, A.G. Nutrição de Monogástricos. Lavras: Editora UFLA, 2006. 301p.

BUTCHER, G.D.; MILES, R.D. [2003]. Egg specific gravity designing a monitoring program. IFAS Extension, University of Florida. Disponível em: <http://edis.ifas.ufl.edu/ VM044>. Acesso em 12/11/2008.

CARD, L.E.; NESHEIM, M.C. Poultry production. 10.ed. Philadelphia: Lea e Febiger, 1966. 400p.

CHOI, J.H.; SO, B.S.; RYU, K.S. et al. Effects of pelleted or crumbled diets on the performance and the development of the digestive organs of broilers. Poultry Science, v.65, n.3, p.594-597, 1986.

COUTO, H.P.; NERY, V.L.H.; FONSECA, J.B. et al. Fontes alternativas de cálcio e fósforo para poedeiras comerciais. Revista Brasileira de Zootecnia, v.37, n.8, p.1419-1423, 2008.

FLEMINIG, R.H.; McCORMACK, H.A.; WHITEHEAD, C.C. Bone structure and strength at different ages in laying hens and effects of dietary particulate limestone, vitamin k, and ascorbic acid. British Poultry Science, v.39, p.434-440, 1998.

GERALDO, A.; BERTECHINI, A.G.; KATO, R.K. et al. Níveis de cálcio e granulometrias do calcário para frangas e seus efeitos sobre a produção e qualidade de ovos. Revista Brasileira de Zootecnia, v.35, n.4, p.1720-1727, 2006.

GERALDO, A.; BERTECHINI, A.G.; MURGAS, L.D.S. et al. Níveis de cálcio e granulometrias do calcário Para frangas de reposição no período de 3 a 16 semanas de idade. Revista Ciência Agrotécnica, v.28, n.2, p.437-442, 2004.

ITO, D.T.; FARIA, D.E.; KUWANO, E.A. et al. Efeitos do fracionamento do cálcio dietário e granulometria do calcário sobre o desempenho e qualidade dos ovos de poedeiras comerciais. Acta Scientiarum Animal Sciences, v.28, n.2, p.187-195, 2006.

JARDIM FILHO, R.M.; STRINGHINI, J.H.; CAFÉ, M.B. et al. Influência das fontes e granulometria do calcário calcítico sobre o desempenho e qualidade da casca dos ovos de poedeiras comerciais. Acta Sientiarum Animal Sciences, v.27, n.1, p.35-41, 2005.

LEESON, S.; SUMMERS, J.D. Commercial poultry nutrition. 2.ed. Guelph: Univ. Books. 1997. 350p.

NARVÁEZ, W.V.; ROSTAGNO, H.S.; SOARES, P.R. et al. Níveis de cálcio para poedeiras comerciais leves de 46 a 62 semanas de idade. In: REUNIÃO ANUAL DA SOCIEDADE BRASILEIRA DE ZOOTECNIA, 34., 1997, Juiz de Fora, Anais... Juiz de Fora: Sociedade Brasileira de Zootecnia, [1997]. (CD-ROM).

OLIVEIRA, J.R.; BERTECHINI, A.G.; FASSANI, E.J. Níveis de cálcio em dietas para poedeiras leves e semipesadas no segundo ciclo de produção. Revista Ciência Agrotécnica, v.26, p.1060-1067, 2002.

PAVLOVSKI, Z.; VITOROVIÆ, D.; LUKIÆ, M. et al. Improving eggshell quality by replacement of pulverised limestone by granular limestone in the hen diet. Acta Veterinária, v.53, n.1, p.35-40, 2003

PAZ, I.C.L.A.; MENDES, A.A.; BALOG, A. et al. Qualidade óssea, produção e qualidade de ovos de poedeiras semi-pesadas em primeiro ciclo de produção. PUBVET, v.2, n.23, 2008.

PELICIA, K.; GARCIA, E.A.; MÓRI, C. et al. Calcium levels and limestone particle size in the diet of commercial layers at the end of the first production cycle. Brazilian Journal of Poultry Science, v.11, n.2, p.87-94, 2009.

RAO, K.S.; ROLAND, D.A. Improved limestone retention in the gizzard of commercial Leghorn hens. Journal Applied Poultry Research, v.1, p.6-10, 1992. 
ROSTAGNO, H.S.; ALBINO, L.F.T.; DONZELE, J.L. et al. Tabelas brasileiras de exigências nutricionais para aves e suínos (Composição de alimentos e exigências nutricionais). 3.ed. Viçosa, MG: Universidade Federal de Vicosa, 2005. 141p.

ROLAND, D.A. Eggshell quality IV: oyster shell versus limestone and the importance of particle size or solubility of calcium source. World's Poultry Science Journal, v.42, p.166-171, 1986.

ROLAND, D.A.; GORDON, R.W. Metabolism and role of phosphorus, calcium and vitamin $\mathrm{D}_{3}$ in layer nutrition. In: COElho, M.B.; KORnegay, E.T. (Eds.) Phytase in animal nutrition and waste management, a BASF reference manual. Mt. Olive: BASF, 1996. p.125-136.

SAUNDERS-BLADES, J.L.; MACISAAC, J.L.; KORVER, D.R. et al. The effect of calcium source and particle size on the production performance and bone quality of laying hens. Poultry Science, v.88, p.338-353, 2009.

STRINGHINI, J.H. Influência da granulometria do calcário calcítico sobre a composição de minerais em tíbias de poedeiras comerciais com diferentes idades. In: CONFERÊNCIA APINCO DE CIÊNCIA E TECNOLOGIA AVÍCOLA, 2004, Santos. Anais... Santos: Conferência Apinco, 2004. p.105.

UNIVERSIDADE FEDERAL DE VIÇOSA - UFV. Sistemas de análises estatísticas e genéticas - SAEG. Versão 5.0. Viçosa, MG, 1983. 59p.

XIN, H.; GATES, R.S.; PUMA, M.C. et al. Drinking water temperature effects on laying hens subjected to warm cyclic environment. Poultry Science, v.81, p.608-617, 2002.

ZHANG, B.; COON, C.N. The relationship of calcium intake, source, size, solubility in vitro and in vivo, and gizzard limestone retention in laying hens. Poultry Science, v.76, p.1702-1706, 1997. 